\title{
USE OF THREE ISOTOPES TO CALIBRATE HUMAN BONE RADIOCARBON DETERMINATIONS FROM KAINAPIRINA (SAC), WATOM ISLAND, PAPUA NEW GUINEA
}

\author{
Fiona Petchey \\ Radiocarbon Dating Laboratory, School of Science and Engineering, University of Waikato, Private Bag 3105, Hamilton, \\ New Zealand. Corresponding author. Email: fpetchey@waikato.ac.nz.
}

\section{Roger Green}

Anthropology Department, University of Auckland, New Zealand.

\begin{abstract}
In archaeological dating, the greatest confidence is usually placed upon radiocarbon results of material that can be directly related to a defined archaeological event. Human bone should fulfill this requirement, but bone dates obtained from Pacific sites are often perceived as problematic due to the incorporation of ${ }^{14} \mathrm{C}$ from a range of different reservoirs into the collagen via diet. In this paper, we present new human bone gelatin results for 2 burials from the SAC archaeological site on Watom Island, Papua New Guinea, and investigate the success of calibrating these determinations using dietary corrections obtained from $\delta^{34} \mathrm{~S}, \delta^{15} \mathrm{~N}$, and $\delta^{13} \mathrm{C}$ isotopes.
\end{abstract}

\section{INTRODUCTION}

There are relatively few early Pacific archaeological sites with human remains (Kirch et al. 1989; Pietrusewsky 1989). Consequently, those remains that have been found are important to the understanding of change over time in burial practices, economy, and the relationships between different populations. Direct dating of these human bones should provide the most secure means of establishing the age of burials, especially in sites where later activities have disturbed the deposits or few datable cultural remains have been found in association. Radiocarbon determinations on human bone protein have, however, often produced ${ }^{14} \mathrm{C}$ results that are at odds with cultural remains (Spriggs 1990:6; Anderson and Clark 1999:36).

It is now apparent that ${ }^{14} \mathrm{C}$ results of human bone protein may be different than expected because of the consumption of marine, freshwater, and terrestrial plants and animals. It has long been known that stable isotopes provide an indication of past human diets, and $\delta^{13} \mathrm{C}$ and/or $\delta^{15} \mathrm{~N}$ isotopic values are currently being used as a quantitative measure of different dietary sources for ${ }^{14} \mathrm{C}$ calibration (Lanting and van der Plicht 1998; Arneborg et al. 1999; Cook et al. 2001, 2002; Schulting and Richards 2002; Bonsall et al. 2004). In general, the success of these calibrations appears to be dependent on the complexity of the diet. Recently, Bayliss et al. (2004) compared the methodologies of Arneborg et al. (1999) and Ambrose (1993:83) using $\delta^{13} \mathrm{C}$ and/or $\delta^{15} \mathrm{~N}$ values, to determine the likely foods eaten by the inhabitants of medieval Timberhill in Norwich. In this instance, each method resulted in different interpretations of the data and significantly different estimates for the chronology of the site (Bayliss et al. 2004:573). This variation could be due to the parameters used as well as the complexity of a diet that, on the basis of archaeological evidence, was dominated by marine foods, low levels of freshwater fish, and legumes. Environmental, physiological, and biochemical processes may also be a factor (Ambrose 1993:85; Ben-David and Schell 2001:183).

Calculating a suitable dietary correction for ${ }^{14} \mathrm{C}$ dates of human bone from the Pacific is especially complex because of a possible combination of marine, reef, and freshwater foods, and $\mathrm{C}_{3}$ and $\mathrm{C}_{4}$ plants. In particular, nitrogen fixation in coral reefs results in lower $\delta^{15} \mathrm{~N}$ values in organisms that subsist in this environment, with some being as low as terrestrial animals (Schoeninger et al. 1983: 220). Similarly, differences in carbon fractionation for $C_{4}$ plants (e.g. sugarcane) result in $\delta^{13} \mathrm{C}$ values that are more positive and difficult to distinguish from marine values. Recognizing this problem for dietary reconstruction, Leach et al. (1996) used a third isotope, $\delta^{34} \mathrm{~S}$, and developed a computer 
simulation program to determine the relative proportions of the main food groups in the diet. This was combined with existing knowledge of $\delta^{13} \mathrm{C}, \delta^{15} \mathrm{~N}$, and $\delta^{34} \mathrm{~S}$ isotopes; calorific content and protein yields of Pacific food types; and geological, archaeological, and metabolic information in order to generate a range of possible food compositions that could have produced the isotope pattern seen. This stochastic model has been used to reconstruct the relative dietary proportions for human remains throughout the tropical Pacific and New Zealand (Leach et al. 2000, 2003).

In this paper, we evaluate the potential of obtaining reliable calibrated ${ }^{14} \mathrm{C}$ results for human bone from the Pacific using dietary information obtained from $\mathrm{S}, \mathrm{N}$, and $\mathrm{C}$ isotope data, following the methodology of Leach et al. $(2000,2003)$. To this end, 2 new ${ }^{14} \mathrm{C}$ determinations of human bone gelatin from the burial ground at Watom have been obtained. The dietary-corrected calibrated results are compared to a mixed calibrated age for the bone, which is determined from linear interpolation between $\delta^{13} \mathrm{C}$ endpoints (cf. Arneborg et al. 1999). The reliability of all calibrated results are evaluated by comparison with ${ }^{14} \mathrm{C}$ determinations from associated contexts and archaeological evidence.

\section{WATOM}

In 1965-7, excavations were undertaken at the SAC site on Watom Island, just off the northeast coast of New Britain (Figure 1). These excavations established the presence of 2 cultural layers buried beneath an ash layer (Zone B). The lower of the 2 cultural deposits (Zone C2) was characterized by the remains of domestic habitation, Late Lapita ${ }^{1}$-style pottery, and fingernail-impressed pottery. A single ${ }^{14} \mathrm{C}$ determination of human bone from Zone $\mathrm{C} 2$ was obtained at the time (ANU-37b; $2420 \pm 110$ BP) (Specht 1968).

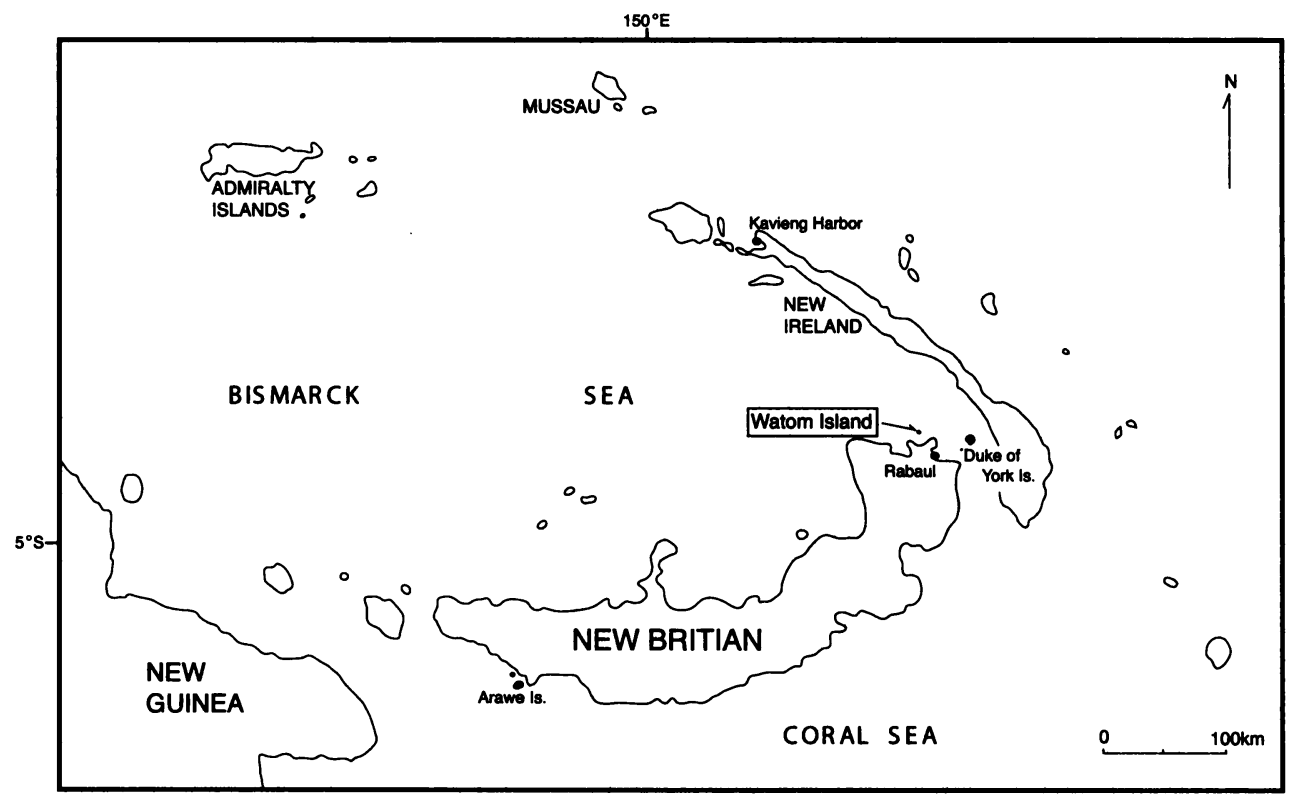

Figure 1 Map of the Bismarck archipelago showing Watom Island and locations mentioned in text

'The remains of the Lapita cultural complex stretch from the Bismarck archipelago to Samoa, and are dated to between $3500 \mathrm{BP}$ and $2000 \mathrm{BP}(1550-50 \mathrm{BC})$. Dentate-stamped pottery is one of the more distinctive components of this complex (Green 1979; Spriggs 1996). 
Following subsequent excavations in 1985,2 more ${ }^{14} \mathrm{C}$ determinations on a single Tridacna shell sample (ANU-5336 [2530 $\pm 90 \mathrm{BP}]$ and Beta-16835 [2470 $\pm 75 \mathrm{BP}]$ ) were obtained for Zone C2. This shell was lodged within the infill of a pit $(\mathrm{g})$ under a pile of stones that spilled into the pit and was considered at the time to be associated with the burial deposits (see Green and Anson 2000:43, Figure 8). The 2 dates returned a pooled calibrated result of 2241-2063 BP at $1 \sigma$ (291-113 BC) (using a $\Delta \mathrm{R}$ of 0 ). A date was also obtained on a sample of Trochus niloticus (ANU-5339: $3490 \pm 80$ $\mathrm{BP}$ ) recovered from the very basal deposits of SAC. This result was considered to be too old to date Zone $\mathrm{C} 2$ given the other ${ }^{14} \mathrm{C}$ results and associated pottery, and was therefore attributed to Zone $\mathrm{D}$ (Green and Anson 2000:38-9). Using this data, Green and Anson (2000:46) proposed an event history for the site that began with the formation of a sandbank around 3450-3250 BP (1300-1500 BC) (Zone D). This was followed by a brief Lapita-age domestic occupation inferred to have begun around $2350 \mathrm{BP}$ (400 BC). After a short interval without activity, the site was used as a burial ground around 2250-2050 BP (300-100 BC) (Zone C2), and the area was later reoccupied for domestic purposes in 2100-1900 BP (150 BC-AD 50) (Zone C1).

The attribution of these burials to the Lapita horizon by Green et al. $(1989: 220)^{2}$ has caused some controversy. Several researchers have expressed doubts about the dating of the site, partly because the burials were considered to be far too young when compared to similar Lapita sites in the region, but also because of uncertainties about the integrity of the deposits (Gosden et al. 1989:563; Spriggs 2001:241; Best 2002:86-9). Recently, analysis of the plant remains at SAC has found no evidence of contamination of Zone C2 by C1 (Lentfer and Green 2003:83), and supports the original excavators' observations that disturbance did not extend between the layers (Green and Anson 2000:84; Specht 2003:132). The reliability of ANU-37b remains in doubt, however, because of the uncertain effect of human diet and unproven relationship to other dated features.

\section{DIETARY INPUT AND THE BURIALS}

Stable isotopes of "collagen" (the fraction remaining after digestion of bone with phosphoric acid) have previously been measured from six of the burials found at SAC (Leach et al. 2000). This data was analyzed by a computer simulation program that was designed to estimate the relative proportions of the main food groups in the diet of prehistoric Pacific peoples (Leach et al. 1996). From this data, Leach et al. (2000) concluded that about $64 \mathrm{wt} \%$ of the diet was land-based and $36 \mathrm{wt} \%$ came from the sea. Moreover, $2.7 \mathrm{wt} \%$ of the diet was obtained from $\mathrm{C}_{4}$ pathway plants (e.g. sugarcane or a herbivore that browsed on the $\mathrm{C}_{4}$ grasslands) and $6 \mathrm{wt} \%$ from reef fish. This hypothesis of a predominantly terrestrial-based diet is supported by trace element analysis (Horward 1988:138) and midden remains that were dominated by pig, with lesser quantities of bandicoot, reptile, and unidentified bird bones (Green and Anson 2000:50-1).

Unfortunately, the human bone ${ }^{14} \mathrm{C}$ determination (ANU-37b) is a mix of material from several of the burials-Burial 1, and possibly burials 2 and 3 (Specht, personal communication, 2002). Dietary variation amongst these individuals has been suggested on the basis of $\delta^{15} \mathrm{~N}$ and $\delta^{34} \mathrm{~S}$ isotope values (Leach et al. 2000:151). Moreover, these individuals could have significantly different burial dates. Variation in the burial practices may also support this possibility: Burial 1 was in a fully extended supine position, whereas burials 2 and 3 belong to a second grouping of articulated flexed burials in oval and rounded pits (Specht 1968:126; Green et al. 1989:219).

\footnotetext{
${ }^{2} \mathrm{~A}$ few sherds of dentate-stamped ware were discovered in Burial 4 (Green et al. 1989:220). Unfortunately, these sherds could not be used to conclusively date the burial, though some would see such a close association as indicative, given no other source for the pit infill than the pottery-bearing layer into which it was excavated.
} 
The reliability of the original bone ${ }^{14} \mathrm{C}$ determination must also be questioned. When pretreated in 1966, ANU-37b was given an acid wash to remove the carbonate fraction (Robertson, personal communication, 2001). This pretreatment is no longer recommended for most archaeological bone samples because significant contamination can be left following pretreatment, depending on the extent of collagen degradation (van Klinken and Hedges 1995:268). Unfortunately, no analysis of the bone preservation state was made at the time of dating, though it was noted during subsequent excavations that the bones were generally in a poor condition, probably because they were within, or just above, the high tide water table (Green and Anson 2000:46). A high C:N ratio of 3.7 obtained by Leach et al. (2000:152) for Burial 3 also suggests some contamination was not removed by the acid wash pretreatment. ${ }^{3}$ Given these uncertainties, it was decided to re-sample and re-date the Watom burials. A separate dating of Burial 3 by another laboratory has also been carried out and will be reported independently of this paper. This result does not provide conflicting evidence of the age of Burial 3.

\section{MATERIAL AND METHOD}

We obtained finely powdered bone from burials 1,2 , and 3, which had been held in storage at Otago University in New Zealand. Gelatin was extracted using a modified Longin method (Longin 1971), which is the standard method for pretreating bones at the Waikato Radiocarbon Dating Laboratory (Petchey and Higham 2000). First, the sample was decalcified in $2 \% \mathrm{w} / \mathrm{v} \mathrm{HCl}$ at $4^{\circ} \mathrm{C}$ for $24 \mathrm{hr}$, then rinsed with distilled water. This acid insoluble collagen was gelatinized by heating in weakly acidic water ( $\mathrm{pH}=3$ at $90^{\circ} \mathrm{C}$ for $4 \mathrm{hr}$ ). The supernatant ("gelatin") was then removed and freeze-dried.

All gelatin stable isotope measurements used for dietary reconstruction were made at GV Instruments, England, using a standard EuroVector ${ }^{\mathrm{TM}}$ elemental analyzer interfaced directly to the ion source of a stable isotope mass spectrometer (see Leach et al. 2003:43 for details). Graphite targets were processed by the Waikato Radiocarbon Dating Laboratory in New Zealand, by the reduction of $\mathrm{CO}_{2}$ with $\mathrm{Zn}$ in a reaction catalyzed by iron powder at a temperature of about $575^{\circ} \mathrm{C}$. The resulting graphite was compressed into a target for measurement at the Rafter Radiocarbon Laboratory, Lower Hutt, New Zealand.

The stable isotope data was analyzed by a computer simulation program that was designed to estimate the relative proportions of the main food groups in the diet of prehistoric Pacific populations (see Leach et al. 1996 for methodology) (Method 1). The parameters used in this diet simulation are given in Appendix 1. The results were compared to \% marine values calculated by linear interpolation using the single isotope option in the program ISOERROR 1.04 (Phillips and Gregg 2001). We selected $\delta^{13} \mathrm{C}$ endpoint values of $-12 \%$ for purely marine and $-21 \%$ for purely terrestrial $\left(\mathrm{C}_{3}\right)$ diets (after Hobson and Collier [1984] for coastal Queenslanders in Australia) (Method 2).

\section{RESULTS}

The success of any bone ${ }^{14} \mathrm{C}$ determination is largely dependent on the preservation state (degree of contamination and degradation) and the pretreatment used to purify and isolate the bone protein. In this instance, the use of several isotopes for dietary reconstruction enabled assessment of the reliability of the data obtained. This is especially important in the Pacific, where hot, humid conditions contribute to rapid bone decay.

Stable isotope and elemental results for burials 1, 2, and 3 are shown in Table 1. Numerous researchers have given guidelines for acceptable "collagen" $\mathrm{C}$ and $\mathrm{N}$ parameters. ${ }^{3}$ All the data collected for the pretreated gelatin from the Watom burials appear to fall within these guidelines. These data can, however, give false positives. Acceptable parameters for sulphur are not as well documented. Rich- 
ards et al. (2001:188) state that modern collagen has a C:S ratio of around 780. For burials 1,2 , and 3 , we obtained values that are significantly lower than this $(\mathrm{C}: \mathrm{S}$ values range from 130.5 for Burial 2 to 389.2 for Burial 3) (Table 1). This suggests a significant loss of protein, which is supported by the low percentages of extractable gelatin for the 3 burials. At the Waikato Radiocarbon Dating Laboratory, a gelatin yield of less than $2 \%$ is generally considered to be of "poor" preservation. ${ }^{14} \mathrm{C}$ results of such low protein bones may be problematic (Petchey 1998). Only Burial 2 fell below this, with a gelatin yield of $1.17 \%$ (Table 1 ).

Table 1 QC data for gelatin from burials 1, 2, and 3 from Watom. ${ }^{\mathrm{a}}$

\begin{tabular}{llllllllll}
\hline Sample & $\%$ yield gel & $\delta^{15} \mathrm{~N}$ & $\delta^{13} \mathrm{C}$ & $\delta^{34} \mathrm{~S}$ & $\% \mathrm{~N}$ & $\% \mathrm{C}$ & $\% \mathrm{~S}$ & $\mathrm{C}: \mathrm{S}$ & $\mathrm{C}: \mathrm{N}$ \\
\hline B1 & 2.10 & 10.9 & -18.1 & 6.5 & $14.16 \pm 0.20$ & $40.55 \pm 0.16$ & $0.50 \pm 0.02$ & 216.5 & 3.34 \\
B2 & 1.17 & 10.7 & -18.5 & 7.5 & $13.91 \pm 0.10$ & $39.10 \pm 0.53$ & $0.80 \pm 0.04$ & 130.5 & 3.28 \\
B3 & 2.40 & 11.1 & -17.8 & 10.1 & $15.08 \pm 0.03$ & $42.23 \pm 0.32$ & $0.29 \pm 0.00$ & 389.2 & 3.27 \\
\hline
\end{tabular}

${ }^{a} \delta^{13} \mathrm{C}$ values were measured relative to the VPDB standard and have errors of $\pm 0.1 \%$. $\delta^{15} \mathrm{~N}$ values were measured relative to the AIR standard and have errors of $\pm 0.2 \%$. $\delta^{34} \mathrm{~S}$ values were measured relative to the VB5 standard for consistency with Leach et al. $(1996,2003)$ and have errors of $\pm 0.5 \%$. Elemental S concentration is measured relative to the CORN standard (Alpha Resources, P.O. Box 199, Stevensville, Michigan 49127, USA) (Morrison, personal communication, January 2005).

bProtein yields were measured as a percentage of the extractable gelatin.

Given these results, we concluded that the gelatin for burials 1 and 3 should be well enough preserved for dietary reconstruction and ${ }^{14} \mathrm{C}$ dating.

\section{CALIBRATION AND DIET}

The $\delta^{13} \mathrm{C}, \delta^{15} \mathrm{~N}$, and $\delta^{34} \mathrm{~S}$ values used for probable diet reconstruction are given in Table $1 .{ }^{14} \mathrm{C}$ data for the burials are shown in Table 2 along with the probable \% marine contribution to the diets as determined using the 2 methods listed above. Details of the diet composition results obtained using the Leach et al. (1996) computer simulation program and all 3 isotopes (Method 1) are given in Appendix 2. Linear interpolation from $\delta^{13} \mathrm{C}$ endpoints (Method 2) tends to give a slightly higher marine contribution than the value obtained from Method 1. The greatest difference was recorded for Burial 1, which has a probable $19 \mathrm{wt} \%$ marine contribution using Method 1 compared to $32 \mathrm{wt} \%$ for Method 2. A higher wt $\%$ marine for Method 2 may be due to the inclusion of $\mathrm{C}_{4}$ foods in the diet, which would result in a more positive $\delta^{13} \mathrm{C}$ signature. The \% marine contribution for burials 2 and 3 are similar using both methods (see Table 2).

Table 2 Results of ${ }^{14} \mathrm{C}$ and stable isotope analyses.

\begin{tabular}{|c|c|c|c|c|c|}
\hline Lab nr & Burial & $\begin{array}{l}{ }^{14} \mathrm{C} \text { age } \pm \\
\text { std. error }\end{array}$ & $\begin{array}{l}\delta^{13} \mathrm{C}(\%) \\
\text { (fractionation correction) })^{\mathrm{a}}\end{array}$ & $\begin{array}{l}\text { \% Marine } \\
\text { (C:N:S) } \\
\text { Method } 1\end{array}$ & $\begin{array}{l}\text { \% Marine } \\
\left(\delta^{13} \mathrm{C}\right) \\
\text { Method } 2\end{array}$ \\
\hline Wk-15567 & 1 & $2757 \pm 32 \mathrm{BP}$ & $-17.97 \pm 0.2$ & 19 & 32 \\
\hline - & 2 & - & - & 22 & 28 \\
\hline Wk-15568 & 3 & $2633 \pm 33 \mathrm{BP}$ & $-17.69 \pm 0.2$ & 37 & 35 \\
\hline
\end{tabular}

${ }^{\mathrm{a}} \delta^{13} \mathrm{C}$ value used to correct for vacuum line fractionation. Measurement carried out at the Stable Isotope Unit, University of Waikato.

\footnotetext{
${ }^{3}$ Modern collagen has about $43 \%$ carbon and $16 \%$ nitrogen and should have a C:N value of about 3.2 (Ambrose and Norr 1993:403). Using data compiled from the Oxford University Radiocarbon Accelerator Unit, van Klinken (1999:691) suggested that most well-preserved archaeological bone protein ranges between 11 and $16 \% \mathrm{~N}$, with an average of $35 \% \mathrm{C}$ and a $\mathrm{C}: \mathrm{N}$ ratio range of 3.1-3.5.
} 
The human bone determinations were calibrated using the mixed calibration option in OxCal v 3.10 (Bronk Ramsey 1995, 2001). This program calculates the calibration curve valid for a given fraction of marine food by linear interpolation between the terrestrial calibration curve of Reimer et al. (2004) and the marine curve of Hughen et al. (2004). We have used an uncertainty of $\pm 10 \%$ for the diet correction, following the recommendations of Ambrose (1993:112), and a reservoir correction $(\Delta R)$ of $261 \pm 101 \mathrm{yr}$ for Watom in order to adjust for regional oceanic variation in ${ }^{14} \mathrm{C}$ (Petchey, unpublished data). To evaluate the difference between the 2 dietary calibration models, ${ }^{14} \mathrm{C}$ determinations are calibrated, combined, and then assessed in light of the combined data. $\angle A n$ is the value (dependent on $n$ ) below which the agreement index $(A)$ should not fall (Bronk Ramsey 1995).

Figure 2 shows the calibrated age ranges for Burial 1 (Wk-15567: $2757 \pm 32 \mathrm{BP}$ ) and Burial 3 (Wk15568: $2633 \pm 33 \mathrm{BP}$ ). The results are compared to published ${ }^{14} \mathrm{C}$ dates from zones $\mathrm{C} 2$ and $\mathrm{C} 1$. The calibrated age range for Burial 1 with a $19 \mathrm{wt} \%$ marine contribution (Method 1) is $2850-2720 \mathrm{BP}$ at $1 \sigma(900-770 \mathrm{BC})$ compared to $2760-2660,2640-2610$, and 2600-2510 BP at $1 \sigma(810-710$, $690-660$, and 650-560 BC) for a $32 \mathrm{wt} \%$ marine contribution (Method 2). These 2 results are in good agreement $(n=2 ; A=118.0[<A n=50.0 \%])$. For Burial 3, the calibrated age range for Method $1(37 \mathrm{wt} \%)$ is 2670-2630, 2620-2590, and 2540-2350 BP at $1 \sigma(720-680,670-640$, and 590-380 BC) compared to 2670-2630, 2620-2590, and 2550-2350 BP at $1 \sigma(720-680,670-640$, and $600-400 \mathrm{BC}$ ) for Method $2(35 \mathrm{wt} \%)$. Again, the results of the 2 methods are almost identical $(n=2 ; A=110.5[<A n=50.0 \%])$.

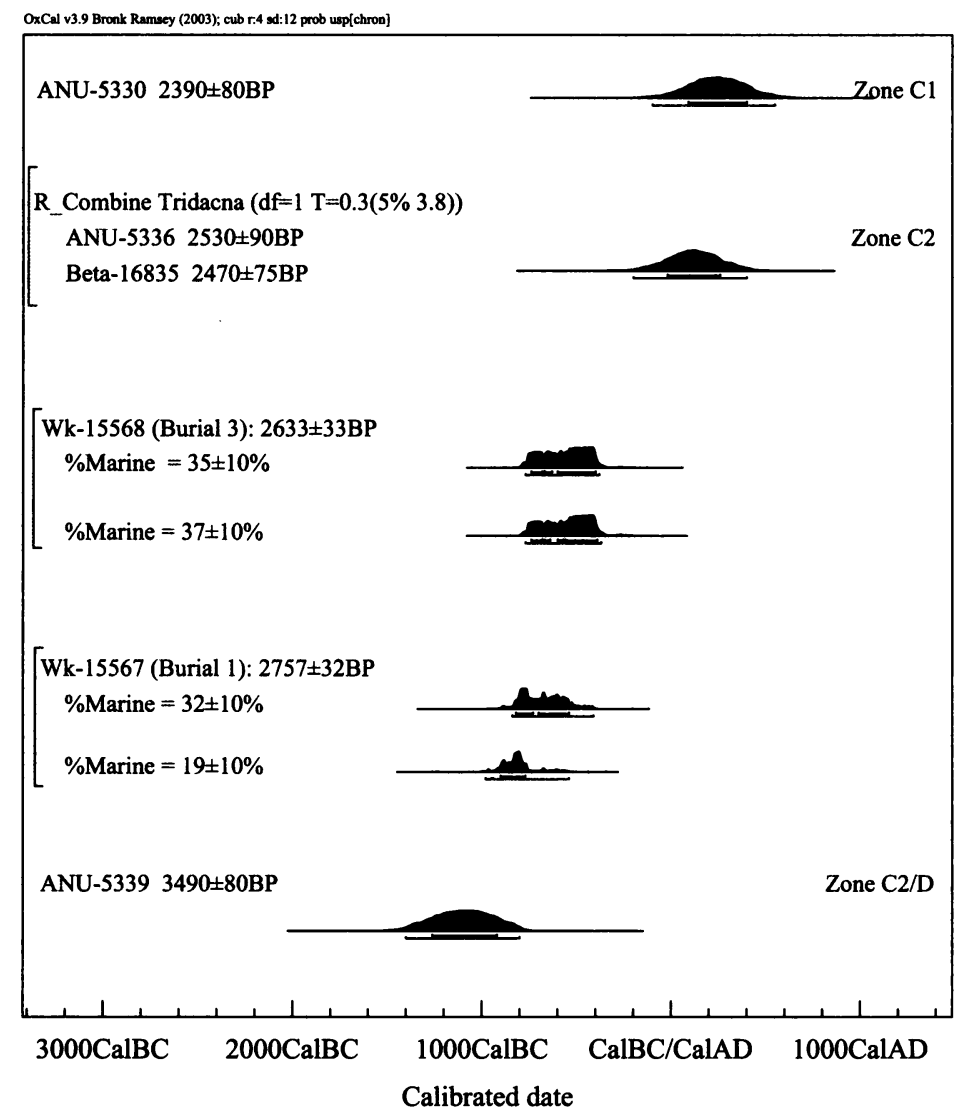

Figure 2 Calibrated ${ }^{14} \mathrm{C}$ determinations from zones $\mathrm{C} 1$ and $\mathrm{C} 2$, SAC, Watom Island. Error bars show 1- and 2- $\sigma$ deviations. 


\section{DISCUSSION}

Neither the use of 3 isotopes (Method 1) nor the linear interpolation from $\delta^{13} \mathrm{C}$ endpoints (Method 2) resulted in calibrated age ranges that were statistically different. In this instance, it is impossible to decide which method is better for calibrating bone samples. However, in areas where reef or $\mathrm{C}_{4}$ foods play a greater role this variance may increase. Unfortunately, available isotope data from Pacific food sources is limited, and the interpretation of dietary input from isotopes is a highly complex area with numerous assumptions. Variation has been attributed to climate (Heaton et al. 1986; Ambrose 1993; van Klinken et al. 1994; Richards and van Klinken 1997; Cook et al. 2002); geographical location (Hobson 1999; Pate et al. 2002; Kelly 2000); the effect of aridity, salinity, inadequate diet (Heaton 1987; Hobson and Clark 1992; Ambrose 1993); and disease (Bayliss et al. 2004). The impact of diet to tissue fractionation is also unresolved (Ambrose and Norr 1993; Tieszen and Fagre 1993; Fogel and Tuross 2003).

Despite these limitations, this research has had several unexpected outcomes. First, the results from burials 1 and 3 are significantly older than the previous date obtained for the burials (ANU-37b; $2420 \pm 110 \mathrm{BP}$ ). This supports our suggestion above that the simple acid wash pretreatment used in 1966 to isolate the bone protein was not sufficient to remove contamination from ANU-37b. Second, these results lend support to the presence of a slightly older Lapita settlement elsewhere on Watom Island, possibly further inland as speculated by Specht (2003:125), and make it highly probable that ANU-5339 was a food shell from an initial occupation of the beach around 3210-2870 cal BP at $1 \sigma(1260-920 \mathrm{BC})$ and was not associated with Zone $\mathrm{D}$. This calibrated result is younger than previously thought because of the application of the new Watom $\Delta \mathrm{R}$ value $(261 \pm 101 \mathrm{yr})$ instead of zero (see Figure 2). Third, these results are also much older than the recalibrated shell dates ANU-5336 (2050-1700 cal BP at $1 \sigma$ [100 BC-AD 250]) and Beta-16835 (1970-1650 cal BP at $1 \sigma$ [20 BC-AD 300]) of a single shell from under a pile of stones in the infill of the pit ( $\mathrm{g}$ ) (see Green and Anson 2000:43, Figure 8). ${ }^{4}$ Green and Anson (2000:45) had used the ${ }^{14} \mathrm{C}$ result for ANU$37 \mathrm{~b}$ and the fact that the dated stone pile seemed to be part of an alignment that delineated the burial area, to suggest that they were contemporary. This relationship is now open to debate and it seems likely that Zone $\mathrm{C} 2$ covers a more extensive sequence of occupation than previously thought.

A total of 8 burials have been recovered from Watom SAC. It is evident that there was some initial activity prior to the interment of burials 2 and 5, and several of the burial pits could be traced in the section well up into Zone $\mathrm{C} 2$, indicating that some depth of deposit had accumulated by the time they were dug (there is no information for burials 1 and 3) (Green and Anson 2000:45). Moreover, Burial 8 was cut by burials 1 and 4, and must therefore be older than both. Similarly, Specht (1968) thought that Burial 2 had been disturbed by the placement of Burial 3. This suggests that neither Burial 1 nor Burial 3 represents the earliest interment activity. Unfortunately, none of the burials have been cut by features that enable a clear sequence of events to be demonstrated. It remains possible, therefore, that the burial ground was in intermittent use for several centuries, a fact that may explain differences in burial practice (see Green et al. 1989:219), though the ${ }^{14} \mathrm{C}$ results for the extended supine Burial 1 and articulated flexed Burial 3 do not support significant differences in age for different burial types. Unfortunately, the only way to currently date the remaining burials is to obtain ${ }^{14} \mathrm{C}$ determinations on the bone, but the flatness of the calibration curve around $2400-2700 \mathrm{yr}$ ago exaggerates the spread in calibrated age range and limits the resolution of the ${ }^{14} \mathrm{C}$ data.

${ }^{4}$ Subsequent re-dating of features within zones $\mathrm{C} 1$ and $\mathrm{C} 2$ at $\mathrm{SAC}$ has confirmed the reliability of all shell ${ }^{14} \mathrm{C}$ results, including ANU-5339 (Petchey, unpublished data). 
From a wider perspective, these new bone dates are closer in age to the result obtained for the basal layer (Zone C4) ${ }^{5}$ at the nearby site of SDI, which Anson (2000:133) suggested should be of similar age to SAC, Zone C2 on the basis of ceramic motif similarities. These results also place the burial deposits closer in age to sites with similar Lapita assemblages in the Bismarck archipelago (e.g. SDP, SEE, and SET from the Duke of York Islands; and FOH, FOL, and FOJ from the Arawe Islands [Gosden et al. 1989; Summerhayes 2001]).

\section{Other Uncertainties}

It is well documented that Lapita populations were seafairing people with well-developed trade links (Green 1996). Evidence from Watom suggests that these individuals were no different, and obsidian recovered from the SAC site has been identified as coming as far away as the Admiralty Islands (540 km away) (Green and Anson 2000:66-7). The possibility that these individuals traveled significantly during their lifetimes places some doubt on the reliability of the $\Delta R$ used in this paper. Petchey et al. (2004) noted that $\Delta R$ from the SW Pacific region tended to be highly variable, which they attributed to intermittent upwelling of depleted ${ }^{14} \mathrm{C}$ in response to major current reversals during the monsoons. This may be manifest in the $\Delta \mathrm{R}$ values from Kavieng Harbor in New Ireland, which range from $508 \pm 60 \mathrm{yr}$ to $298 \pm 50 \mathrm{yr}$. In contrast, $\Delta \mathrm{R}$ values from the Coral Sea (southeast coast of New Britain) are much lower, and Petchey et al. (2004) suggest that currents originating from here influence the $\Delta R$ for the Duke of York Islands $(\Delta R=39 \pm 68 \mathrm{yr})$, less than $40 \mathrm{~km}$ from Watom Island. No information is available for the southwest coast of New Britain, though we think it is likely that this region is also influenced by low $\Delta R$ values from the Coral Sea. Moreover, $\Delta R$ results on pre-1950 shells collected from Rabaul Harbor, $20 \mathrm{~km}$ from Watom, indicate a wide range of values (Petchey, unpublished data), some of which predate the creation of the caldera that forms the harbor (approximately $1400 \mathrm{BP}$ ) and are likely to be influenced by volcanic activity. This identified range in $\Delta R$ could further limit the resolution of ${ }^{14} \mathrm{C}$ determinations of both shell and human bone from Watom and other sites in this region.

\section{CONCLUSION}

Two new human bone ${ }^{14} \mathrm{C}$ determinations have been obtained for burials 1 and 3 from SAC on Watom Island. $\delta^{13} \mathrm{C}, \delta^{15} \mathrm{~N}$, and $\delta^{34} \mathrm{~S}$ data have been used to apply a correction to these dates for the consumption of different foods. Although the influence of marine foods on the ${ }^{14} \mathrm{C}$ calibration is significant, the impact of other food types in this instance is negligible. We recommend that human bone determinations from the Pacific must have $\delta^{13} \mathrm{C}$ and $\delta^{15} \mathrm{~N}$ isotopes measured in order to obtain reliable calibrations. The use of a third isotope, $\delta^{34} \mathrm{~S}$, is recommended where $\mathrm{C}_{4}$ and reef foods make up a significant portion of the diet. Moreover, all bones from Pacific archaeological sites should have a minimum gelatin pretreatment and be assessed for degradation and contamination prior to dating. Currently, our ability to obtain usable human bone calibrated dates is influenced more by the availability of accurate marine offsets $(\Delta R)$ and the removal of contamination during pretreatment than by the exactness of dietary reconstruction.

These 2 new gelatin determinations place the age of burials 1 and 3 within the first half of the 1st millennium BC. These results are significantly older than previous assessments for the burials and necessitate a reassessment of the chronology of later features within Zone C2 at the SAC site and the relationship of this burial ground to Lapita sites elsewhere in the Bismarck archipelago.

${ }^{5}$ Beta-16836 (3020 $\pm 90 \mathrm{BP}$; Tridacna sp.) has a calibrated age of 2670-2330 BP at $1 \sigma(720-380 \mathrm{BC})$ when calibrated with a $\Delta R$ of $261 \pm 101 \mathrm{yr}$. 


\section{ACKNOWLEDGMENTS}

We are indebted to John Morrison (GV Instruments, Manchester, England) for providing the stable isotope data; Foss Leach (Museum of New Zealand) for running the computer simulations, locating bone from the Watom burials, and discussions about diet; and Nancy Tayles (Anthropology Dept, Otago University) for access to the Watom bone samples. We would also like to thank Jim Specht (Australian Museum, Sydney) for supplying information on the Watom burials, and Steve Robinson (Research School of Earth Sciences, Australian National University) for tracking down ${ }^{14} \mathrm{C}$ data associated with the dating of ANU-37b. We are indebted to the Waikato Radiocarbon Dating Laboratory and Dr Alan Hogg for funding the dating of burials 1 and 3.

\section{REFERENCES}

Ambrose SH. 1993. Isotopic analysis of paleodiets: methodological and interpretive considerations. In: Sandford MK, editor. Elemental and Isotopic Analyses: Understanding Diet and Disease in Past Populations. New York: Gordon and Breach Science Publishers. p 59-130.

Ambrose SH, Norr L. 1993. Experimental evidence for the relationship of the carbon isotope ratios of whole diet and dietary protein to those of bone collagen and carbonate. In: Malbert JB, Grupe G, editors. Prehistoric Human Bone: Archaeology at the Molecular Level. Berlin: Springer-Verlag. p 1-38.

Anderson A, Clark G. 1999. The age of Lapita settlement in Fiji. Archaeology in Oceania 34:31-9.

Arneborg J, Heinemeier N, Lynnerup HL, Nielsen N, Sveinbjörnsdóttir ÁE. 1999. Change of diet of the Greenland Vikings determined from stable carbon isotope analysis and ${ }^{14} \mathrm{C}$ dating of their bones. Radiocarbon 41(2): 157-68.

Anson D. 2000. Reber-Rakival dentate-stamped motifs: documentation and comparative implications. New Zealand Journal of Archaeology 20(1998):119-35.

Bayliss A, Sheppard Popescu E, Beavan Athfield N, Bronk Ramsey C, Cook GT, Locker A. 2004. The potential significance of dietary offsets for the interpretation of radiocarbon dates: an archaeologically significant example from medieval Norwich. Journal of Archaeological Science 31:563-75.

Ben-David M, Schell DM. 2001. Mixing models in analysis of diet using multiple stable isotopes: a response. Oecologia 127:180-4.

Best S. 2002. Lapita: A View from the East. Dunedin North: New Zealand Archaeological Association Monograph 24.

Bonsall C, Cook GT, Hedges REM, Higham TFG, Pickard C, Radovanović I. 2004. Radiocarbon and stable isotope evidence of dietary change from the Mesolithic to the Middle Ages in the Iron Gates: new results from Lepenski Vir. Radiocarbon 46(1):293-300.

Bronk Ramsey C. 1995. Radiocarbon calibration and analysis of stratigraphy: the OxCal program. Radiocarbon 37(2):425-30.

Bronk Ramsey C. 2001. Development of the radiocarbon calibration program. Radiocarbon 43(2A):355-63.

Cook GT, Bonsall C, Hedges REM, McSweeney K, Boroneant V, Pettitt PB. 2001. A freshwater diet-derived ${ }^{14} \mathrm{C}$ reservoir effect at the Stone Age sites in the Iron Gates Gorge. Radiocarbon 43(2A):453-60.

Cook GT, Bonsall C, Hedges REM, McSweeney K, Boroneant V, Bartosiewicz L, Pettitt PB. 2002. Problems of dating human bones from the Iron Gates. Antiquity 76:77-85.

Fogel ML, Tuross N. 2003. Extending the limits of paleodietary studies of humans with compound specific carbon isotope analysis of amino acids. Journal of Archaeological Science 30:535-45.

Gosden C, Allen J, Ambrose W, Anson D, Golson J, Green R, Kirch P, Lilley I, Specht J, Spriggs M. 1989. Lapita sites of the Bismarck archipelago. Antiquity 63: 561-86.

Green RC. 1979. Lapita. In: Jennings JD, editor. The Prehistory of Polynesia. Cambridge: Harvard University Press. p 27-60.

Green RC. 1996. Prehistoric transfers of portable items during the Lapita horizon in remote Oceania: a review. Indo-Pacific Prehistory Association Bulletin 15:11929.

Green RC, Anson D. 2000. Excavations at Kainapirina (SAC), Watom Island, Papua New Guinea. New Zealand Journal of Archaeology 20(1998):29-94.

Green RC, Anson D, Specht J. 1989. The SAC burial ground, Watom Island, Papua New Guinea. Records of the Australian Museum 41:215-21.

Heaton THE. 1987. The ${ }^{15} \mathrm{~N} /{ }^{14} \mathrm{~N}$ ratios of plants in South Africa and Namibia: relationship to climate and coastal/saline environments. Oecologia 74:236-6.

Heaton THE, Vogel JC, Chevallarie G, Collett G. 1986. Climatic influence on the isotopic composition of bone nitrogen. Nature 322:822-3.

Hobson KA. 1999. Tracing origins and migration of wildlife using stable isotopes: a review. Oecologia 120:314-26.

Hobson KA, Clark RG. 1992. Assessing avian diets using stable isotopes II: factors influencing diet-tissue fractionation. Condor 94:189-97.

Hobson KA, Collier S. 1984. Marine and terrestrial pro- 
tein in Australian Aboriginal diets. Current Anthropology 25:238-40.

Horward M. 1988. Trace elements and prehistoric diet in the Pacific: a study of six human groups from bone strontium, zinc and magnesium concentrations [unpublished MA thesis]. Otago: Department of Anthropology, University of Otago.

Hughen KA, Baillie MGL, Bard E, Beck JW, Bertrand CJH, Blackwell PG, Buck CE, Burr GS, Cutler KB, Damon PE, Edwards RL, Fairbanks RG, Friedrich M, Guilderson TP, Kromer B, McCormac G, Manning S, Bronk Ramsey C, Reimer PJ, Reimer RW, Remmele S, Southon JR, Stuiver M, Talamo S, Taylor FW, van der Plicht J, Weyhenmeyer CE. 2004. Marine04 marine radiocarbon age calibration, 0-26 cal kyr BP. Radiocarbon 46(3): 1059-86.

Kirch PV, Swindler DR, Turner CG II. 1989. Human skeletal and dental remains from Lapita sites (1600$500 \mathrm{BC}$ ) in the Mussau Islands, Melanesia. American Journal of Physical Anthropology 79:104-15.

Lanting JN, van der Plicht J. 1998. Reservoir effects and apparent ${ }^{14} \mathrm{C}$ ages. The Journal of Irish Archaeology IX:151-65.

Leach BF, Quinn CJ, Lyon GL. 1996. A stochastic approach to the reconstruction of prehistoric human diet in the Pacific region from bone isotope signatures. Tuhinga, Records of the Museum of New Zealand Te Papa Tongarewa 8:1-54.

Leach BF, Quinn CJ, Lyon GL, Haystead A, Myers DB. 2000. Evidence of prehistoric Lapita diet at Watom Island, Papua New Guinea, using stable isotopes. New Zealand Journal of Archaeology 20(1998):149-59.

Leach BF, Quinn C, Morrison J, Lyon G. 2003. The use of multiple isotope signatures in reconstructing prehistoric human diet from archaeological bone from the Pacific and New Zealand. New Zealand Journal of Archaeology 23(2001):31-98.

Lentfer CJ, Green RC. 2003. Phytoliths and the evidence for banana cultivation at the Lapita Reber-Rakival site on Watom Island, Papua New Guinea. In: Attenbrow V, Fullagar R, editors. A Pacific Odyssey: Archaeology and Anthropology in the Western Pacific. Papers in Honour of Jim Specht. Records of the Australian Museum, Supplement 29:75-88.

Longin R. 1971. New method of collagen extraction for radiocarbon dating. Nature 230:241-2.

Pate FD, Brodie R, Owen TD. 2002. Determination of geographic origin of unprovenanced Aboriginal skeletal remains in South Australia employing stable carbon and nitrogen isotope analysis. Australian Archaeology 55:1-7.

Petchey F. 1998. Radiocarbon analysis of a novel bone sample type: snapper and barracouta bone from New Zealand archaeological sites [PhD dissertation]. Waikato: University of Waikato.

Petchey F, Phelan M, White P. 2004. New $\Delta R$ values for the southwest Pacific Ocean. Radiocarbon 46(2): 1005-14.
Petchey F, Higham TFG. 2000. Bone diagenesis and radiocarbon dating of fish bone at the Shag River Mouth site, New Zealand. Journal of Archaeological Science 27:135-50.

Phillips DL, Gregg JW. 2001. Uncertainty in source partitioning using stable isotopes. Oecolgia 127:171-9.

Pietrusewsky M. 1989. A study of skeletal and dental remains from Watom Island and comparisons with other Lapita people. Records of the Australian Museum 41(3):235-92.

Reimer PJ, Baillie MGL, Bard E, Bayliss A, Beck JW, Bertrand CJH, Blackwell PG, Buck CE, Burr GS, Cutler KB, Damon PE, Edwards RL, Fairbanks RG, Friedrich M, Guilderson TP, Hogg AG Hughen KA, Kromer B, McCormac G, Manning S, Bronk Ramsey C, Reimer RW, Remmele S, Southon JR, Stuiver M, Talamo S, Taylor FW, van der Plicht J, Weyhenmeyer CE. 2004. IntCal04 terrestrial radiocarbon age calibration, 0-26 cal kyr BP. Radiocarbon 46(3):1029-58.

Richards MP, van Klinken GJ. 1997. A survey of European human bone stable carbon and nitrogen isotope values. In: Sinclair AGM, Slater EA, Gowlett JAJ, editors. Archaeological Sciences 1995. Oxford: Oxbow Monograph 64. p 363-8.

Richards MP, Fuller BT, Hedges REM. 2001. Sulphur isotopic variation in ancient bone collagen from $\mathrm{Eu}$ rope: implications for human paleodiet, residence mobility, and modern pollutant studies. Earth and Planetary Science Letters 191:185-90.

Schoeninger MJ, DeNiro MJ, Tauber H. 1983. Stable nitrogen isotope ratios of bone collagen reflect marine and terrestrial components of prehistoric human diet. Science 220:1381-3.

Schulting RJ, Richards MP. 2002. Finding the coastal Mesolithic in southwest Britain: AMS dates and stable isotope results on human remains from Caldey Island, South Wales. Antiquity 76:1011-25.

Specht JR. 1968. Preliminary report on excavations on Watom Island. Journal of the Polynesian Society 77: 117-34.

Specht JR. 2003. Watom Island and Lapita: observations on the Reber-Rakival localities. In: Sand C, editor. $\mathrm{Pa}$ cific Archaeology: Assessments and Prospects. Proceedings of the International Conference for the 50th anniversary of the first Lapita excavation. KonéNouméa 2002. p 122-34.

Spriggs MJT. 1990. Dating Lapita: another view. In: Spriggs M, editor. Lapita Design Form and Composition. Proceedings of the Lapita Design Workshop, Canberra, Australia, December 1988. Occasional Papers in Prehistory 19. Department of Prehistory, Research School of Pacific Studies, Australian National University, Canberra. p 6-27.

Spriggs MJT. 1996. Chronology and colonization in island Southeast Asia and the Pacific: new data and an evaluation. In: Davidson J, Irwin G, Leach F, Pawley A, Brown D, editors. Oceanic Culture History: Essays in Honour of Roger Green. New Zealand Journal of 
Archaeology Special Publication.

Spriggs MJT. 2001. Who cares what time it is? The importance of chronology in Pacific archaeology. In: Anderson A, Lilley I, O'Connor S, editors. Histories of Old Ages: Essays in Honour of Rhys Jones. Canberra: Pandanus Books, Research School of Pacific and Asian Studies, ANU. p 237-49.

Stuiver M, Reimer PJ, Braziunas S. 1998. High precision radiocarbon age calibration for terrestrial and marine samples. Radiocarbon 40(3):1127-51.

Stuiver M, Reimer PJ, Bard E, Beck JW, Burr GS, Hughen KA, Kromer B, McCormac FG, van der Plicht J, Spurk M. 1998. IntCal98 radiocarbon age calibration, 24,000-0 cal AD. Radiocarbon 40(3):1041-83.

Summerhayes GR. 2001. Defining the chronology of Lapita in the Bismarck archipelago. In: Clark GR, Anderson AJ, Vunidilo T, editors. The Archaeology of Lapita Dispersal in Oceania. Papers from the Fourth Lapita Conference, June 2000. Canberra: Pandanus
Books, Research School of Pacific and Asian Studies, ANU. p 25-38.

Tieszen LL, Fagre T. 1993. Effect of diet quality and composition on the isotopic composition of respiratory $\mathrm{CO}_{2}$, bone collagen, bioapatite and soft tissues. In: Malbert JB, Grupe G, editors. Prehistoric Human Bone: Archaeology at the Molecular Level. Berlin: Springer-Verlag. p 121-55.

van Klinken GJ. 1999. Bone collagen quality indicators for paleodietary and radiocarbon measurement. Journal of Archaeological Science 26:687-95.

van Klinken GJ, Hedges REM. 1995. Experiments on collagen-humic interactions: speed of humic uptake, and effects of diverse chemical treatments. Journal of Archaeological Science 22:263-70.

van Klinken GJ, van der Plicht H, Hedges REM. 1994. Bone ${ }^{13} \mathrm{C} /{ }^{12} \mathrm{C}$ ratios reflect (paleo-)climatic variations. Geophysical Research Letters 21(6):445-8.

\section{APPENDIX 1: PARAMETERS USED FOR DIET SIMULATION OF WATOM BURIAL DATA}

- Range of acceptable energy consumption: 1800.0 to $3700.0 \mathrm{kcal}$ per day

- Range of acceptable protein consumption: 25.0 to $200.0 \mathrm{~g}$ per day

- Isotope offsets from food to collagen:

$\delta^{13} \mathrm{C}+5.0$

$\delta^{15} \mathrm{~N}+3.0$

$\delta^{34} \mathrm{~S}-0.5$ for land foods

$\delta^{34} \mathrm{~S}-0.9$ for marine foods

Appendix la Mean values for each food.

\begin{tabular}{lcrrcc}
\hline Food & $\delta^{13} \mathrm{C}$ & $\delta^{15} \mathrm{~N}$ & $\delta^{34} \mathrm{~S}$ & Protein $\mathrm{g} / 100 \mathrm{~g}$ & $\mathrm{kcal} \mathrm{g} / 100 \mathrm{~g}$ \\
\hline 1 = C 3 plants & -26.0 & 5.8 & 4.9 & 2.2 & 145.0 \\
2 = C 4 plants & -11.5 & 10.0 & 4.9 & 0.4 & 38.0 \\
3 = Land herbivores & -22.6 & 5.4 & 4.4 & 23.1 & 155.0 \\
4 = Marine shellfish & -14.0 & 7.2 & 18.6 & 12.9 & 69.0 \\
5 = Coral reef fish & -12.6 & 7.9 & 17.7 & 19.7 & 100.0 \\
6 = Non-reef fish & -16.5 & 14 & 17.7 & 19.7 & 100.0 \\
7 = Marine mammals & -16.8 & 15.7 & 16.8 & 14.0 & 262.0 \\
\hline
\end{tabular}

aIt is assumed that marine mammals did not contribute to Watom diet (see Leach et al. 2000:151).

Appendix lb Population isotope values and tolerance values for testing.

\begin{tabular}{lccc}
\hline Isotope & Burial 1 & Burial 2 & Burial 3 \\
\hline$\delta^{13} \mathrm{C}$ & -18.1 & -18.5 & -17.8 \\
$\delta^{15} \mathrm{~N}$ & 10.9 & 10.7 & 11.1 \\
$\delta^{34} \mathrm{~S}$ & 6.5 & 7.5 & 10.1 \\
Tolerance & & & \\
$\delta^{13} \mathrm{C}$ & 1.0 & 1.2 & 2.0 \\
$\delta^{15} \mathrm{~N}$ & 1.5 & 1.2 & 1.5 \\
$\delta^{34} \mathrm{~S}$ & 1.5 & 1.2 & 1.5 \\
\hline
\end{tabular}


APPENDIX 2: WATOM DIET COMPOSITION FROM COMPUTER SIMULATIONS

Appendix 2: Watom diet composition., ${ }^{\mathrm{a}, \mathrm{b}}$

\begin{tabular}{|c|c|c|c|c|c|c|}
\hline & \multicolumn{2}{|c|}{ Burial 1} & \multicolumn{2}{|c|}{ Burial 2} & \multicolumn{2}{|c|}{ Burial 3} \\
\hline & Mean & SD & Mean & SD & Mean & SD \\
\hline Energy kcal/day & 2414.1 & 484.0 & 2449.2 & 483.5 & 2152.3 & 294.9 \\
\hline Protein g/day & 156.9 & 30.4 & 155.9 & 29.3 & 173.0 & 20.0 \\
\hline$\delta^{13} \mathrm{C}$ & -17.5 & 0.4 & -17.6 & 0.3 & -16.2 & 0.3 \\
\hline$\delta^{15} \mathrm{~N}$ & 9.9 & 0.3 & 10.0 & 0.4 & 10.7 & 0.7 \\
\hline$\delta^{34} \mathrm{~S}$ & 6.7 & 0.7 & 7.1 & 0.5 & 9.0 & 0.4 \\
\hline
\end{tabular}

Food weight $\%$

$\mathrm{C}_{3}$ plants

57.8

$9.6 \quad 60.3$

8.8

49.8

6.6

$\mathrm{C}_{4}$ plants

5.4

3.9

3.5

2.6

2.8

2.1

Land herbivores

18.2

11.4

14.7

10.4

10.3

7.2

Marine shellfish

5.0

4.1

4.2

11.3

7.7

Coral reef fish

4.5

3.8

4.7

3.8

7.0

6.0

Non-reef fish

9.1

5.1

11.4

5.2

18.7

9.4

Marine mammals

$0.0 \quad 0.0$

0.0

0.0

0.0

Protein g/day

$\mathrm{C}_{3}$ plants

24.01

8.19

25.24

7.89

19.47

4.91

$\mathrm{C}_{4}$ plants

0.42

0.35

0.27

0.24

0.20

0.17

Land herbivores

71.29

38.30

57.93

35.40

39.36

25.12

Marine shellfish

12.30

11.16

13.62

11.50

26.49

19.97

Coral reef fish

16.58

15.01

17.36

15.14

24.33

21.08

Non-reef fish

32.28

19.06

41.49

20.32

63.16

31.13

Marine mammals

0.0

0.0

0.0

0.0

0.0

0.0

\section{Energy kcal/day}

$\mathrm{C}_{3}$ plants

$\mathrm{C}_{4}$ plants

$1582.21 \quad 539.7$

$39.66 \quad 33.54$

1663.23

520.27

1283.27

\begin{tabular}{l}
323.88 \\
\hline
\end{tabular}

Land herbivores

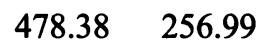

$25.65 \quad 22.35$

$388.74 \quad 237.53$

$19.17 \quad 15.69$

Marine shellfish

65.80

72.87

61.51

$264.09 \quad 168.52$

Coral reef fish

84.19

59.68

$88.13 \quad 76.84$

141.67

106.84

Non-reef fish

163.86

76.17

$210.62 \quad 103.13$

$123.48 \quad 106.98$

Marine mammals

0.0

0.0

$0.0 \quad 0.0$

320.61

158.03

a Total number of simulations attempted: 31,968,404 (Burial 3); 157,338,945 (Burial 2); 49,437,707 (Burial 1).

${ }^{b}$ Number of successful simulations: 5024 (Burial 3); 10,180 (Burial 2); 6850 (Burial 1). 